eikon journal on semiotics

\title{
Francisca Amorim
}

\section{The political rhetoric of Hitler in the light of The Origins of Totalitarianism by Hannah Arendt}

Adolf Hitler is widely recognized as one of the greatest orators in History. He had great knowledge of the rhetorical art, and knew how to disseminate anti- semitism, imperialism and totalitarianism in Germany between the decades of 1930 and 1940 of the twentieth century. In this paper, we analyze the German Reichstag speech of February 20th, 1938. We aim at decomposing and exemplifying Hitler's political rhetoric, by confronting it with The Origins of Totalitarianism by Hannah Arendt, a fundamental work for understanding Nazi ideologies and propaganda. The trajectory of discourse analysis follows the five canons of rhetoric, which cross the elaboration of a speech - invention, disposition, elocution, memory and action - and addresses the means of persuasion of Aristotle - ethos, pathos and logos.

Keywords

Adolf Hitler, Hannah Arendt, Rhetoric, Politic, Totalitarianism, Antisemitism.

\section{A retórica política de Hitler à luz d'As Origens do Totalitarismo de Hannah Arendt}

Adolf Hitler é reconhecidamente um dos maiores oradores da história. Tinha grandes conhecimentos da arte da retórica e soube-se dela apropriar para disseminar o antissemitismo, o imperialismo e o totalitarismo na Alemanha entre os anos 30 e 40 do século XX. Neste trabalho, analisa-se o discurso proferido no Reichstag alemão a 20 de fevereiro de 1938. Propomo-nos decompor e exemplificar a retórica política hitleriana, colocando-a em confronto com As Origens do Totalitarismo de Hannah Arendt, obra fundamental para a compreensão das ideologias e da propaganda do nazismo. A trajetória da análise segue as cinco fases da retórica, transversais à elaboração de um discurso - invenção, disposição, elocução, memória e ação - e aborda os meios de persuasão de Aristóteles - ethos, pathos e logos.

\section{Palavras-chave}

Adolf Hitler, Hannah Arendt, Retórica, Política, Totalitarismo, Antissemitismo. 
"O poder só é efetivado enquanto a palavra e o ato não se divorciam, quando as palavras não são vazias e os atos não são brutais, quando as palavras não são empregadas para velar intenções, mas para revelar realidades e os atos não são usados para violar e destruir, mas para criar relações e novas realidades."

Hannah Arendt in A Condição Humana

Em pleno século XXI, a Europa é maioritariamente governada pela democracia. De um ponto de vista legal, os homens são livres e têm direito a participar na vida política, trocando ideias e debatendo-as. Argumentar é, pois, um ato essencial para o exercício cívico. É assim que a retórica, entendida como uma técnica de bem falar, de comunicar eficazmente, está intrinsecamente relacionada com o sistema político democrático. A retórica surgiu em Siracusa, como forma de resolução de um problema gerado pela tirania. ${ }^{1}$ Ao longo dos tempos, o poder da palavra sobressaiu face à violência e à dominação, dando lugar ao debate e ao entendimento. Todavia, nos anos 30 e 40 do século XX, a ditadura nazi na Alemanha, liderada por Adolf Hitler, deunos uma lição sobre o poder da retórica usada para, num regime democrático, instaurar uma ditadura.

De modo a ilustrar isto, propomos analisar um discurso proferido por Hitler à luz da obra As Origens do Totalitarismo da filósofa política alemã Hannah Arendt. É uma forma de o confrontar, tendo em conta que são duas perspetivas da essência da política que estão em evidência: a vontade democrática e a vontade totalitária. Por um lado, temos a visão despótica de Hitler, chefe máximo do governo, que concentra em si toda a autoridade na regulação da vida da Nação. E, por outro lado, Hannah Arendt que defendia o pluralismo político, o direito a cada um ser livre para expressar de igual modo a sua opinião e interagir na vida da sociedade.

O discurso de Hitler aqui em causa foi proferido no Reichstag (Parlamento) alemão a 20 de fevereiro de 1938. Hitler dirigia-se a uma audiência composta por elementos do seu partido, o único permitido na Alemanha. Nesta altura, o regime nazi, em vigor desde 1933, caminhava para o seu apogeu. Este discurso surge, então, cerca de um mês antes da anexação da Áustria, no âmbito da criação do Terceiro Reich (Império Alemão), e antes da invasão da Polónia, que contextualiza o início da Segunda Guerra Mundial, em setembro do ano seguinte.

A obra As Origens do Totalitarismo de Hannah Arendt será publicada em 1951, seis anos depois da derrota da Alemanha na guerra, constituindo a reunião de um pensamento que testemunhou a criação do governo totalitário alemão. Hannah Arendt era de origem judaica e viuse forçada a abandonar o seu país quando Hitler subiu ao poder. Este assunto era-lhe, portanto, muito caro, e não o quis deixar cair no esquecimento. Pensadora da política, retrata neste livro as ideologias que guiavam o regime nazi, ou seja, o antissemitismo, o imperialismo e o totalitarismo, dedicando a cada uma delas um capítulo. É uma ajuda fundamental para compreender a génese de uma estrutura de poder fundada na total dominação dos cidadãos e na crença da superioridade rácica. Mas também para perceber a força retórica da palavra, graças à descrição da transformação das classes em massas e ao papel da propaganda, tão eficaz quanto a difusão do medo e da violência. Han- nah Arendt mostra bem quanto os argumentos retóricos são uma sobreposição de elementos lógicos (do logos), emotivos (do pathos) e credíveis (do ethos). Pareceu-nos ainda que um estudo de Retórica Política tinha toda a conveniência em analisar estes dois textos, colocando-os em confronto direto, quer porque coincidiam na mesma época e nos mesmos temas, quer porque o fazem em campos antagónicos.

Aristóteles, na sua obra Retórica, define-a como "a capacidade de descobrir o que é adequado a cada caso com o fim de persuadir" (2005: 95). Hitler tinha essa capacidade. Conhecedor exímio daquela que é "geradora de persuasão" (Platão) e a "ciência de bem falar" (Quintiliano), soube usá-la, ainda que da forma mais horrenda, para manipular o povo alemão. É tendo em conta o pensamento e o contributo aristotélico que o presente estudo se desenvolve. Para Aristóteles, "as provas de persuasão fornecidas pelo discurso são de três espécies: umas residem no caráter moral do orador; outras no modo como se dispõe o ouvinte; e outras, no próprio discurso" (2005: 96). Cada discurso combina, assim, respetivamente, o ethos, o pathos e o logos, e é pela análise de cada uma delas que melhor se compreende uma capacidade retórica.

\section{Reconhecer os meios da retórica no discurso de Adolf Hitler}

\section{Ethos. Caráter.}

O ethos corresponde ao caráter do orador. Segundo Aristóteles, "persuade-se pelo caráter quando o discurso é proferido de tal maneira que deixa a impressão de o orador ser digno de fé" (2005: 96). Ora, Hitler ao longo do discurso fala maioritariamente na terceira pessoa do plural, não atribuindo o sucesso da Alemanha apenas a si, mas incluindo todo o povo alemão. Contudo, essa aparente honestidade serve apenas para se louvar, mostrando-se pessoa superior, graças à qual a Alemanha, desde que o tem no poder, evoluiu: "A seguir aos Estados Unidos, a Alemanha é hoje o maior produtor de aço do mundo... São provas documentais de uma obra nunca antes conseguida pelo nosso povo". Não perde também a oportunidade para mostrar a sua autoridade: "Eu tinha o direito de me virar contra todos aqueles que, em vez de ajudarem, pensavam que a sua missão era criticarem a nossa obra". E, sempre que the convém, revela-se ponderado e um defensor do seu povo: "Acaba por tornar-se insuportável para uma potência mundial, consciente de si própria, saber que existem cidadãos ao seu lado aos quais são constantemente infligidos os mais duros sofrimentos..." Deste modo, para além de construir o seu ethos através de argumentos ad hominem, ou seja, centrados nas características de quem argumenta e não na pura lógica dos seus argumentos, vai paralelamente disseminando as suas ideias e objetivos que, perante um modo de parecer, e não de ser, tão altruísta, ganham mais força e adesão.

\section{Pathos. Emoção.}

O pathos são os sentimentos que o orador consegue exprimir e/ou provocar na sua audiência. "Persuade-se pela disposição dos ouvintes, quando estes são levados a sentir emoção por meio do discurso, pois os juízos que 
fazemos variam conforme sentimos tristeza ou alegria, amor ou ódio" (Aristóteles, 2005: 97). O apelo através deste meio é muito utilizado por Hitler, de modo a conseguir manipular o público sem mostrar que o quer fazer. Este discurso é muito informativo, contudo o que Hitler pretende é mostrar que o caminho que a Alemanha tem levado é o correto, atribuindo- Ihe frases positivas, enquanto ataca a ideologia da Rússia e da Grã-Bretanha, criando emoções negativas destas. Por exemplo: "Se, durante estes cinco anos, tivéssemos agido como os cosmopolitas e democráticos cidadãos da Rússia Soviética não teríamos conseguido transformar a Alemanha, que se encontrava em profundo colapso material, num país de grandeza material". Já frases como esta - "No final da próxima década, o povo alemão recordará o êxito da sua eficiência e encherse-á de um orgulho supremo" - em termos retóricos são vazias, porque focadas na emoção e não na argumentação. A propósito disto constata Hannah Arendt em As Origens do Totalitarismo:

"A propaganda totalitária aperfeiçoou o cientificismo ideológico e a técnica de afirmações proféticas a um ponto antes ignorado de eficiência metódica e absurdo de conteúdo porque, do ponto de vista demagógico, a melhor maneira de evitar discussão é tornar o argumento independente de verificação no presente e afirmar que só o futuro lhe revelará os méritos" (1998: 395).

É na parte final do discurso que o pathos é mais evidente. O discurso toma um tom ainda mais imperativo e as frases têm uma certa beleza que emotiva. Vejamos: "O povo alemão não é um povo bélico. É uma nação marcial, o que significa que não deseja a guerra mas não a teme. Ama a paz mas também ama a sua honra e a sua liberdade". Hitler termina apelando a Deus e à força e coragem do povo, procurando chegar ao coração de quem o escuta.

\section{Logos. Razão.}

O logos consiste na racionalidade do discurso, nos argumentos lógicos apresentados. Por isso, "persuadimos, enfim, pelo discurso quando mostramos a verdade ou o que parece ser verdade, a partir do que é persuasivo em cada caso particular" (Aristóteles, 2005: 97). O discurso em causa é toda uma tentativa de Hitler argumentar o que defende através de uma lógica baseada na emoção. Já vimos como a Alemanha é louvada ao ser apresentada como um caso de sucesso, e as outras nações, como a Rússia bolchevista, que é a "incarnação das forças destrutivas humanas", são menosprezadas. O máximo do logos encontra-se a meio do discurso quando Hitler enumera em cinco pontos as considerações que tem relativamente à Liga das Nações. Tal permite cativar os recetores para seguirem o seu entendimento, todavia apenas porque os seus argumentos devem ser assimilados. A aparente lógica do seu discurso recorre a fundamentos onde implicitamente há uma emoção que procura influenciar. Afinal não há explicação evidente para criticar o bolchevismo na Rússia utilizando os judeus, nem verdade no argumento da sua inferioridade racial. De facto, como apresentado, a ideologia cientificista, que cria justificações falsas para uma conduta imoral e cujo objetivo é alcançar o poder e a dominação, foi um dos recursos utilizados por Hitler nos seus discursos. Aliada à confiança que transparecia, tendo em conta que se dirigia a massas analfabetas e, neste caso, a companheiros no mal, era quase suficiente para ter os efeitos desejados.

Esta dimensão tripla do argumento (logos, pathos, ethos) molda grande parte da compreensão da Retórica Política: vai do argumento lógico ao paralógico, das ideias evocadas às subentendidas pela memória, do texto imaginado à concretização do texto, da ideia ao facto. E porque o nosso estudo tem toda a conveniência em ser o mais abrangente possível, procuramos sistematizá-lo através das cinco funções da retórica, transversais, pelo menos desde Quintiliano, à elaboração de um discurso e à sua apresentação perante um público. A Inventio ou Invenção, a Dispositio ou Disposição, a Elocutio ou Elocução, a Memoria ou Memória e a Actio ou Ação são, assim, também as partes em que este trabalho se organiza, analisando a presença de cada uma delas no discurso de Hitler e nas reflexões de Hannah Arendt. No que diz respeito à Invenção, aos argumentos do orador, a opção metodológica passa por confrontá-los com a visão de Hannah Arendt n'As Origens do Totalitarismo, de forma a pôr em conflito a ideologia antissemita, imperialista e totalitária presente nos discursos do Führer (líder). Na Disposição, relativa à organização dos argumentos, procura-se perceber se o discurso segue a estrutura tripartida típica - exórdio, narração e conclusão - e a sua ordem evolutiva. Na Elocução tem-se em conta a escolha das frases, das palavras e do tom. Na Memória, a interiorização de um discurso, mostra-se como esta é uma parte fundamental no caso do antissemitismo e do totalitarismo. E, por fim, discute-se a Ação, a apresentação do discurso, tendo em conta o conhecimento sobre os gestos, a postura e a voz de Hitler.

\section{Inventio. Invenção.}

O discurso de Hitler, proferido no Reichstag a 20 de fevereiro de 1938, discute vários assuntos, sendo, por isso, longo. Em traços gerais, tem como linhas de abordagem o engrandecimento dos feitos da Alemanha desde que ele se encontra no poder, a crítica às nações estrangeiras, principalmente a Inglaterra, que acusa de uma campanha na imprensa contra si, a depreciação da democracia e também do bolchevismo na Rússia, a reivindicação das ex-colónias alemãs, o abandono da Liga das Nações e a anexação da Áustria. As ideologias antissemita, imperialista e totalitária, que Hitler tentava sempre afirmar, estão presentes ao longo de todo o discurso, muitas vezes dissimuladas nos argumentos que apresenta.

\section{I.1. Antissemitismo}

O antissemitismo, o preconceito face aos judeus, constituiu uma das bases da propaganda hitleriana. É visível neste discurso alguns argumentos de Hitler que justificam porque entendia ser imperativo a eliminação desse povo. Logo no segundo parágrafo do discurso afirma: "Se, durante este cinco anos, tivéssemos agido como os cosmopolitas e democráticos cidadãos da Rússia Soviética, ou seja, como os da raça judaica, não teríamos conseguido transformar a Alemanha num país de grandeza material". Hitler procura realçar a evolução que graças à sua governação a Alemanha sofreu, mas fá-lo desdenhando os judeus e culpando-os do anterior atraso do país. Eles são o bode expiatório usado pelo líder nazi para justificar uma forjada superioridade racial ariana, que através das pala- 
vras convencia o povo. Mas os argumentos contra os judeus continuam, pois culpa-os do bolchevismo existente na Rússia. O anticomunismo de Hitler misturava-se com o preconceito antissemita e racista, acusando comunistas e judeus de conspirarem para dominar o mundo: "... vemos no bolchevismo a incarnação das forças destrutivas humanas. Não culpamos o povo russo por esta terrível ideologia de destruição. Sabemos que foi um pequeno grupo de judeus intelectuais que conduziu esta grande nação à sua situação de loucura (...) Infelizmente, o bolchevismo internacional judeu tenta insinuar-se nas nações do mundo a partir do seu centro soviético."

Em As Origens do Totalitarismo, o antissemitismo é a primeira ideologia que Hannah Arendt analisa, acerca da qual refere: "a discriminação torna-se o ponto de cristalização de um movimento político, que deseja resolver através da violência e da lei do populacho todos os conflitos e dificuldades naturais de um país multinacional" (1998: 77). De facto, é evidente o recurso de Hitler aos judeus para neles acomodar tudo o que de mau a seu ver na Alemanha e nos países de esquerda havia. Arendt encontra uma justificação histórica para a escolha dos judeus, até porque "uma ideologia que tem de persuadir e mobilizar as massas não pode escolher a sua vítima arbitrariamente" (1998: 27). Assim, a argumentação de Hitler encontrou força no descontentamento geral da população face ao Estado, "porque o único grupo que parecia representar o Estado eram os judeus" (1998: 45). Para Arendt, este seria o momento em que "a discriminação se transformava em argumento político" (1998: 45). Do ponto de vista retórico, a argumentação da escritora pressupõe que há uma relação entre os factos devido à sua simultaneidade. Estamos, assim, em presença de um argumento cum hoc ergo propter hoc.

\section{I.2. Imperialismo}

O imperialismo é também uma ideologia presente no regime nazi, enquanto esforço de expansão e domínio territorial da superior nação alemã sobre os territórios fronteiriços. No discurso em estudo é percetível o anseio de Hitler por reaver as colónias perdidas com a derrota alemã na Primeira Guerra Mundial: "A reivindicação da posse das colónias alemãs será ouvida todos os anos com um vigor crescente. Estas possessões que a Alemanha não roubou a outros países... são indispensáveis para o nosso povo". Mas demonstra principalmente a política imperialista, baseada numa crença de superioridade biológica, quando afirma que existem "milhões de alemães em estados adjacentes à Alemanha", cujos direitos de autodeterminação racial os unem ao Reich. Por isso, garante a "protecção dos povos germânicos ao longo das nossas fronteiras". A situação da Áustria, que um mês depois da enunciação deste discurso é anexada ao Império Alemão, é exposta já que "o que liga o Reich à Áustria não é apenas o mesmo povo mas também uma longa história e cultura comuns".

Hannah Arendt revela-nos, já no capítulo sobre o Imperialismo, que "o racismo é a principal arma ideológica da política imperialista" (1998: 190). Fica, pois, evidente na argumentação de Hitler que é essa a justificação para as medidas que defende relativas aos territórios. Como constatou a filósofa relativamente ao imperialismo alemão, "o pensamento racial dos alemães resultou do esforço de unir o povo contra o domínio estrangeiro. Os seus autores não procuraram aliados além das fronteiras: buscaram despertar no povo a consciência de uma origem comum" (1998: 195). O argumento do

"racismo, que negava a origem comum do homem e repudiava o objetivo comum de estabelecer a humanidade, introduziu o conceito da origem divina de um povo em contraste com todos os outros, encobrindo assim com uma nuvem pseudomística de eternidade e finalidade o que era resultado temporário e mutável do engenho humano" (1998: 266).

As afirmações de Hitler consolidam os argumentos usados pela eficaz máquina de propaganda do regime para legitimar a ideologia do imperialismo. Exemplificam como a questão da dominação dos territórios de origem germânica e de raça ariana era fundamentada numa proveniência comum, o que justificava a exterminação daqueles que pertenciam a uma raça inferior. Esta questão tocava particularmente a Hannah Arendt, que tinha origem judaica, e, por isso, foi levada a sair da Alemanha e a ser considerada apátrida. Não é por acaso que entende que "a raça é, do ponto de vista político, não o começo da humanidade mas o seu fim, não a origem dos povos mas o seu declínio, não o nascimento natural do homem mas a sua morte antinatural" (1998: 187).

\section{I.3. Totalitarismo}

O totalitarismo é, enfim, a ideologia que caracteriza toda a política levada a cabo por Hitler. O Estado encontrava neste depositada toda a autoridade, não havendo lugar para a participação cidadã. E a regulamentação da vida da sociedade e o controlo das massas eram conseguidas através da difusão de valores, como o antissemitismo e o imperialismo, a restrição da liberdade, o uso do terror e da propaganda política. Neste discurso Hitler profere uma frase que é capaz por si só de resumir a essência do totalitarismo: "O mundo verá então, com a rapidez de um relâmpago, até que ponto este Reich, povo, partido e forças armadas estão fanaticamente inspirados com um só espírito, uma única vontade". O Reich, império territorial alemão, o povo de origem germânica, o partido único nazi e as forças armadas, as SS, eram comandados por Hitler, o líder que tinha o poder total sobre eles. Daí que seja evidente ao longo de todo o discurso a procura pelo engrandecimento dos feitos alcançados pela Alemanha desde que Hitler se encontra no poder. Afinal, o "povo que deveria ser apresentado como um modelo" relativamente às nações estrangeiras, apresenta uma "obra nunca antes conseguida". Há um afastamento constante face aos países que representam a democracia ou o comunismo, porque "o $A B C$ do nosso credo consistiu em encontrarmos apoio na nossa própria força".

Essa força só foi possível graças à manipulação das massas, como conclui Hannah Arendt ao destacar o papel da propaganda na construção do regime totalitário. A adesão de todo um povo aos ideais nazis e a partilha de uma existência comum foi antes de mais possível porque a propaganda aproveitou a sua desunião, o desinteresse político e o analfabetismo. De tal modo que, "o que convence as massas não são os factos, mesmo que sejam factos inventados, mas apenas a coerência com o sistema do qual esses factos fazem parte" (1998: 401). No fundo, não foi simplesmente pela convicção dos elementos da ideologia 
totalitária que ela triunfou, mas porque as massas não tinham capacidade de distinguir o verdadeiro do ficcionado. Serve isto também no que diz respeito aos discursos do Führer, que, segundo a autora, tinha "o hábito de anunciar as suas intenções políticas sob a forma de profecias" (1998: 398). Fá-lo no discurso em causa, recorrendo a um argumento messiânico sobre o crescimento da produção na Alemanha: "No final da próxima década, o povo alemão recordará o êxito da sua eficiência e encher-se-á de um orgulho supremo".

Hannah Arendt resume da seguinte forma esta ideologia:

"O totalitarismo no poder usa a administração do Estado para o seu objetivo a longo prazo de conquista mundial e para dirigir as subsidiárias do movimento; instala a polícia secreta na posição de executante e guardiã da experiência doméstica de transformar constantemente a ficção em realidade; e, finalmente, erige campos de concentração como laboratórios especiais para o teste do domínio total." (1998: 442).

O regime alemão comprova como o conhecimento das técnicas de retórica é essencial na consolidação da ideologia totalitária. Tanto quanto incutir o medo e o terror na população, a palavra manipulada teve força para alienar as massas. É isso que as seguintes fases da retórica procuram demonstrar.

\section{Dispositio. Disposição.}

A disposição é a parte da retórica que se preocupa com a organização das ideias e a relação que estabelecem entre si. Comummente, um discurso encontra-se dividido em três partes - exórdio, desenvolvimento e conclusão -, que correspondem à expectativa da audiência face a ele: a primeira parte apresenta-lhe o que se está a falar, depois é-lhe fornecido mais dados sobre o assunto, e no fim oferece-se uma expectativa sobre tudo o que foi abordado. Atentemos no modo como o discurso de Hitler se encontra disposto.

Na primeira parte, o exórdio ou introdução, procura-se cativar o auditório e apresentar-lhe a temática do discurso. Hitler não faz grandes introduções, começando logo por acusar a imprensa estrangeira de calúnias sobre "um povo que deveria ser apresentado como um modelo a esses apóstolos da democracia". Procura, elogiando os alemães, conquistar a simpatia do Reichstag. Depois, refere-se à missão que a Alemanha tem pela frente, conseguida através do trabalho do povo, realçando que "as intenções da maliciosa campanha da imprensa internacional" não vão travar a construção do sucesso da Alemanha.

Na segunda parte do discurso, o desenvolvimento, apresenta-se a argumentação, neste caso relativa às intenções da nova Alemanha, juntamente com as provas que as confirmam. Assim, para reivindicar a posse das excolónias e realçar o crescimento económico do país, e de modo a comprovar os seus feitos, Hitler compara-o com a Grã-Bretanha, pois conseguiu reduzir o número de desempregados, mesmo não tendo as "grandes vantagens económicas" desse país que "dificilmente consegue resolver os seus problemas de desemprego". Parte depois para a crítica à Liga das Nações, que a Alemanha abandonou aquando do início da sua governação, porque "acreditamos que não é uma instituição de justiça mas sim uma in- stituição para defender os interesses de Versalhes". Apresenta de seguida cinco considerações e justificações para tal, que faz questão de enumerar, o que ajuda o público a seguir o raciocínio: "Em primeiro lugar...", "Em segundo lugar....... Entra, então, numa nova discussão, sobre a sua relação com os países estrangeiros. Por um lado, desdenha a Rússia devido aos judeus e ao bolchevismo, e a França e a Inglaterra pela campanha de imprensa feita contra si. Por outro lado, simpatiza com a Itália, porque "nesse país a política do estado e a política da imprensa andam de mãos dadas", e com o Japão, pois "como a Alemanha, identificaram o bolchevismo como um perigo mundial". A referência à anexação da Áustria a certa altura do discurso serve, pois, para justificar o argumento que faz antes sobre a defesa dos cidadãos de estados adjacentes à Alemanha ligados a si por uma origem comum.

$\mathrm{Na}$ terceira e última parte, a conclusão, recorda-se o mais importante a reter pelo auditório: "O novo Reich (...) Ajudará o povo a encontrar um caminho mais fácil neste mundo. Ajudá-lo-á a tornar o seu destino mais feliz". Há uma ligação emotiva entre esta parte e o desenvolvimento, verificando-se uma ampliação do sentimento da missão alemã ao apelar a Deus que "ajude a encontrar o caminho certo que traçou para o povo alemão". O totalitarismo hitleriano utilizou a sacralização do poder político como instrumento de manipulação, o que é evidente neste excerto do discurso. Hitler coloca Deus do lado dos alemães, o que significa que ele é o encarregado divino de os guiar pelo caminho traçado. Mas este é um argumento que tem duas faces, pois subentende-se também que os inimigos, os judeus e os comunistas, têm do seu lado o Diabo.

\section{Elocutio. Elocução.}

A terceira dimensão da retórica, a elocução, consiste na preocupação com a linguagem, com a escolha das frases, das palavras, dos ritmos e dos sons que formam o discurso. Hitler sabia bem como se expressar perante o seu público para obter o melhor resultado possível. No discurso em análise, o Führer utiliza uma linguagem simples que, apesar de expositiva, é também emotiva. Começa a falar recorrendo a uma apresentação lógica e racional das suas ideias, para isso usando expressões como "ou seja", "por esta mesma razão", "por outras palavras". Servem para justificar os seus argumentos relativamente ao sucesso da Alemanha, por depreciação das nações estrangeiras. Quando termina a sua exposição coloca uma interrogação retórica que reforça a sua tese: "Não é uma piada da história que os países que estão constantemente em crise pensem que podem criticar-nos e dar-nos conselhos?". Podia ser dito de forma afirmativa ou mesmo exclamativa, mas ganha um tom irónico e estabelece uma relação com o público quando colocado na forma interrogativa. Outro exemplo da manipulação da linguagem para realçar os argumentos é o recurso à anáfora, a repetição de uma parte da frase no início de grupos de palavras que se sucedem. Neste caso repete-se "se uma nação que", cujo efeito é a enfatização dos feitos alemães face à Grã-Bretanha. A argumentação de Hitler baseia-se no desdém, seja dos judeus, de países com outras ideologias, ou da Liga das Nações. Ao recusar tudo o que eles significam, fica ciente o que deve ser pensado por aqueles que o escutam. É repetitivo na mensagem que quer passar, dedicando várias frases ao mesmo assunto. Tem um raciocínio preto no branco, de 
tal forma que se saiba quem deve ser odiado e quem deve ser respeitado.

O final é a parte do discurso em que Hitler faz um apelo emocional aos seus ouvintes. Foca-se no povo alemão, pois é por ele que todos os esforços são feitos. Afigura-se conhecedor da profecia que prevê a regeneração futura da Alemanha, recorrendo a Deus, a quem delega a escolha do caminho que o país toma. Hannah Arendt constatou na sua obra, como já foi referido, que Hitler tinha o hábito de anunciar os seus desejos políticos sob a forma de profecias. Não é por acaso que termos como "feliz", "coragem" ou "determinação" são associados a essa mensagem. As palavras finais empolgam e são as que mais facilmente são retidas na memória de quem o escuta.

\section{Memoria. Memória.}

A memória é o cânone da retórica que trata da interiorização do discurso. Quando ele é sabido de cor por quem o dita e não lido parece muito mais natural, sendo possível olhar o público nos olhos; parece vir do coração. Hitler tinha noção disso quando se dirigia às massas. As massas de alemães no desemprego, que tinham visto a Alemanha vencida na Primeira Guerra Mundial e que tinham presente a humilhação sofrida pela sua nação. Foi face a esse cenário negativo que persistia na memória alemã, que Hitler aproveitou para disseminar a ideia de que a esquerda e também os judeus entregaram a Alemanha a um tratado de paz que "provocou consequências a longo prazo nas vidas dos povos envolvidos", como afirma no discurso em análise. Ideia que fez aumentar a simpatia para com a extrema-direita e, consequentemente, pôr fim à democracia. Constitui essa ideia o argumento apocalítico de Hitler, já que as consequências foram destruidoras, em alternativa ao argumento messiânico de que com ele a Alemanha se desenvolveria.

Mas a memória não é só importante para os alemães, os recetores dos discursos de Hitler. É também para os milhares de pessoas que durante a sua liderança foram perseguidas, humilhadas e assassinadas apenas por serem de origem judaica. Como o poderiam esquecer os judeus? Como poderia esquecer a humanidade o Holocausto, uma das fases mais sombrias da história? A memória é, pois, um elemento crucial no caso do antissemitismo e do totalitarismo alemão. Está em causa uma memória coletiva, a memória de um povo que compartilhou o mesmo destino, passando a fazer parte da sua identidade ao longo das gerações. Uma memória, portanto, a longo prazo. A criação de um Dia Internacional em Memória das Vítimas do Holocausto revela a importância de lembrar, todos os anos, a história e aqueles que nela padeceram. Comemorado a 27 de janeiro, a data coincide com o dia de libertação do campo de concentração Auschwitz-Birkenau em 1945. Enfim, porque poder recordar é poder ser livre.

Ao contrário do que vemos atualmente, com a publicação de obras e estudos e a realização de conferências sobre o tema, o genocídio dos judeus na Segunda Guerra Mundial era então pouco debatido e noticiado. Por isso, em As Origens do Totalitarismo, publicada seis anos após a queda de Hitler, Hannah Arendt quis que o Holocausto não caísse no esquecimento e fizesse parte da nossa memória social, como também quis explicar e compreender o passado. Segundo palavras da própria Hannah Arendt, As Origens do Totalitarismo procura "examinar e suportar conscientemente o fardo que os acontecimentos colocaram sobre nós - sem negar a sua existência nem vergar humildemente a seu peso... encarar a realidade, espontânea e atentamente, e resistir a ela..." (1998: 21).

Deste modo, para que o mesmo mal não se repita e porque a História serve de exemplo:

"Já não podemos nos dar ao luxo de extrair aquilo que foi bom no passado e simplesmente chamá-lo de nossa herança, deixar de lado o mau e simplesmente considerá-lo um peso morto, que o tempo, por si mesmo, relegará ao esquecimento" (1998: 13).

Também Primo Levi, judeu sobrevivente a Auschwitz, sentiu "a necessidade de contar aos "outros", de tornar os "outros» conscientes" (2010: 9). Em Se Isto é um Homem, obra memorialística publicada em 1947, partilha a sua experiência do Holocausto para que não se coloque em causa uma possível criação fictícia, deixando claro que "nenhum dos factos é inventado" (2010: 10). A certa altura do livro questiona "se será útil guardar alguma memória desta condição humana anormal" (2010: 89). Responde afirmativamente, pois

"nenhuma experiência humana é privada de sentido e indigna de ser analisada... e deste mundo particular de que estamos a falar se podem tirar valores fundamentais, mesmo que nem sempre positivos" (2010: 89)

Para além de lembrar as vítimas, é também importante lembrar as circunstâncias da história, neste caso lembrar o papel da força retórica na prossecução de um mal.

\section{Actio. Ação.}

A quinta e última parte da retórica é a Ação. A forma como o discurso é exteriorizado, tendo em conta os gestos, a postura, a expressão e a voz do orador. Nesta matéria retórica Hitler tinha também a lição bem estudada. Tornou-se de conhecimento público que Hitler preparava os seus discursos. Ensaiava o tom da voz, de forma a ser mais lento e apagado umas vezes e outras mostrar-se mais empolgado, e os gestos e expressões faciais que a acompanhavam. Planeava um homem divinizado aos olhos dos que o escutavam, e de quem queria retirar as reações desejadas. Para influenciar as massas o seu grande trunfo foi, portanto, a retórica e a oratória:

"Iniciando de maneira relativamente pausada e com uma voz baixa, profunda, era só no final que vociferava e berrava (...) Tenacidade e carisma apenas não teriam feito de Hitler o Führer da Alemanha. Ele precisou ainda vender a si mesmo e à sua visão... e o principal meio sempre foi o show do discurso político" (Roberts, 2004: 46).

Essa característica enunciação de Adolf Hitler transparecia a sua admiração pelo compositor de óperas alemão Richard Wagner. De tal forma que se assemelhava às suas óperas: um começo calmo, que encadeava numa repetição de ideias, terminando em apogeu. Apercebemo-nos disto na análise da disposição retórica. 


\section{Conclusão}

Vivendo numa democracia e estando conscientes das atrocidades, como o Holocausto, por que a humanidade atravessou parece-nos claro que este sistema político é, pelo menos até então, o que tem em conta a liberdade e o pluralismo como essencial à vida humana e política. $\mathrm{Na}$ obra em estudo, As Origens do Totalitarismo, ao abordar a instauração dos regimes totalitários, Hannah Arendt descreve a rejeição da pluralidade humana:

"A pluralidade é a condição da ação humana pelo facto de sermos todos os mesmos, isto é, humanos, sem que ninguém seja exatamente igual a qualquer pessoa que tenha existido, exista ou venha a existir" (2007: 16).

Este trabalho leva-nos a refletir como países onde a democracia não está bem consolidada e que passam por períodos de instabilidade económica ou social estão suscetíveis a cair em tentações totalitárias. O caso da Alemanha nazi revela-nos como o conhecimento retórico de um líder autoritário consegue manipular massas desesperadas e, assim, levar à imposição de um regime totalitário baseado em ideais racistas. O tema mostra-se atual perante as crises económicas que assolam os estados-nação, que se imergem em políticas de austeridade e veem os partidos de extrema-direita ganhar cada vez mais adeptos. Primo Levi já alertava para que "a história dos campos de extermínio deveria ser interpretada por todos como um sinal sinistro de perigo" (2010: 9). E também Hannah Arendt, na obra à luz da qual o discurso neste estudo foi analisado, em jeito de prevenção futura afirmava:

"As soluções totalitárias podem muito bem sobreviver à queda dos regimes totalitários sob a forma de forte tentação que surgirá sempre que pareça impossível aliviar a miséria política, social ou económica de um modo digno do homem" (1998: 511).

Entendemos hoje melhor do que nunca como a retórica é tão importante para defender ideias como para desmascarar mentiras. O totalitarismo nazi é, quiçá, o melhor exemplo para ilustrar como a palavra, tanto quanto a violência, funcionou como arma de terror e de persuasão, capaz de mobilizar as massas no seguimento de ideologias desumanas. Os discursos de Adolf Hitler faziam parte do grande aparelho de propaganda política que existia por detrás da sua imagem e conquistas. Propagava ideias e controlava a opinião do povo, abordando de forma muito emocional quase sempre os mesmos temas: o ódio aos judeus, o desemprego, o orgulho nacional e os seus inimigos, como o discurso analisado corroborou. A repetição, enquanto técnica retórica, era, pois, uma estratégia privilegiada. E, assim, também o argumentum ad nauseam, pois algo é tanto mais verídico e justo quanto mais vezes for repetido o argumento, e também o argumentum ad numerum, já que uma afirmação é tanto mais verdadeira quanto mais pessoas nela digam acreditar. Para além disso, como afirma Hannah Arendt,

"o que caracteriza a propaganda totalitária melhor do que as ameaças diretas e os crimes contra indivíduos é o uso de insinuações indiretas, veladas e ameaçadoras contra todos os que não deram ouvidos aos seus ensinamentos, seguidas de assassinato em massa perpetrado igualmente contra 'culpados' e 'inocentes'" (1998: 394).
A retórica hitleriana é um modelo único da retórica negra, a retórica usada para o mal. É-o a tal ponto que foi criado o argumento reductio ad hitlerum, segundo o qual um fundamento quando relacionado com Hitler ou com o nazismo é considerado inválido ${ }^{2}$. Assim, aquilo que Hitler apoiou é imediatamente entendido como algo mau. A retórica de Hitler não prevê que o auditório reflita e se expresse criticamente, mas forma antes uma argumentação que pretende ludibriar o público e persuadi-lo de uma mentira. Deste modo, faz todo o sentido a conhecida expressão de Hannah Arendt,

"banalidade do mal» ${ }^{3}$. Com ela, a filósofa pretendia demonstrar que o mal que se instalou na Alemanha, levando ao Holocausto, se deveu também ao facto do povo ser acrítico, amorfo, incapaz de questionar as ideologias que lhe incutiam. Neste cenário, a violência torna-se trivial e tudo o que é dito por quem tem autoridade é aceite e interiorizado como dogma. Hitler conhecia bem essa audiência a que se dirigia e, por isso mesmo, soube dominá-la com mestria. Construiu uma retórica perversa, baseada no antissemitismo e no apelo emocional. Uma retórica que deu origem a uma comunicação eficaz, com capacidade para tudo, até a de afetar o curso da História da humanidade.

\footnotetext{
1 "A Retórica nasceu de processos de propriedade. Cerca de 485 a.C., dois tiranos sicilianos, Gelão e Hierão, efectuaram deportações, transferências de população e expropriações, para povoar Siracusa e lotear os mercenários; quando foram depostos por uma sublevação democrática e se quis voltar à ante qua, houve processos inumeráveis, pois os direitos de propriedade eram pouco claros. Estes processos eram de um novo tipo: mobilizavam grandes júris populares, diante dos quais, para os convencer, era necessário "ser eloquente". Esta eloquência, ao participar simultaneamente da democracia e da demagogia, do judicial e do político constituiu-se rapidamente em objecto de ensino" (Barthes, 1987: 23).
}

${ }^{2}$ Cf. STRAUSS, Leo. (2009). Direito Natural e História. Lisboa: Edições 70.

${ }^{3}$ Cf. ARENDT, Hannah. (2003). Eichmann em Jerusalém - Uma reportagem sobre a banalidade do mal. $2^{a}$ edição. Coimbra: Edições Tenacitas. 


\section{Referências bibliográficas}

ARENDT, Hannah. (2007). As Origens do Totalitarismo. $3^{\text {a }}$ reimpressão. Tradução: Roberto Raposo. São Paulo: Companhia das Letras.

ARENDT, Hannah. (2007). A Condição Humana. 10a edição. Tradução: Roberto Raposo. Rio de Janeiro: Forense Universitária.

ARISTÓTELES. Retórica. (2005). $2^{\mathrm{a}}$ edição. Tradução: Manuel Alexandre Júnior et al. Lisboa: Imprensa $\mathrm{Na}$ cional Casa da Moeda.

BARTHES, Roland. (1987). A Aventura Semiológica. Tradução: Maria de Santa Cruz. Lisboa: Edições 70.

LEVI, Primo. Se Isto é um Homem. (2010). $7^{\text {a }}$ edição. Tradução: Simonetta Cabrita Neto. Lisboa: Teorema.

ROBALO, Manuel e MATA, Miguel. (2005). 50 Grandes Discursos da História. Lisboa: Edições Sílabo, pp. 79-86. [consultado em 2016-0325]. Disponível online:

<https://curteahistoria.wikispaces.com/file/view/Dis curso+de+Adolfo+Hitler+Proferido +no+Reichstag+em+20+Fevereiro+de+1938.pdf > .

ROBERTS, Andrew. (2004). Hitler \& Churchill: Segredos da Liderança. Tradução: Maria Luíza Borges. Rio de Janeiro: Jorge Zahar Editor. 


\section{Anexo / Documento prático}

Retirado de ROBALO, Manuel e MATA, Miguel. (2005). 50 Grandes Discursos da História. Lisboa: Edições Sílabo, pp. 79-86.

\section{ADOLF HITLER}

"O mundo verá então, com a rapidez de um relâmpago, até que ponto este Reich, povo, partido e torças amadas estâo fanaticamente inspirados com um só espirito, uma única vontade.

[Discurso proferido no Reichstag - 20 de Fevereiro de 1938]

\section{As Intençōes da Nova Alemanha}

O prenúncio da Segunda Guerra Mundial. Após um longo e tortuoso percurso politico, íniciado no principio da década de 1920. Adolf Hitter conduz - Partido Nazi a excelentes resultados nas eleiçőes parlamentares de 1930 1932, baseando a sua popularidade numa retórica xenóloba, nacionalista. anti-semita e anti-comunista. Dernocraticamente colocado numa posiçấo charneira da polltica alemá, Hitler é nomeado chanceler em 30 de Janeiro de

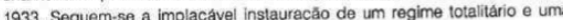
politice pollsca ox erra cadora causto.

Temos assistido a uma autêntica inundaçẵo de mentiras $\mathrm{e}$ calúnias espalhods por alguma imprensa estrangeira. Foi uma notável combi-

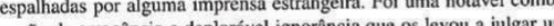
nação de arrogância e deplorável ignorância que os levou a juigar um povo que deveria ser apresentado como um modelo a esses apóstolos
da democracia.

A melhor maneira de expor estas mentiras é o sucesso. Se, durante estes cinco anos, tivéssemos agido como os cosmopolitas e democráticos cidadãos da Rússia Soviética, ou seja, como os da raça judaica, não teríamos conseguido transformar a Alemanha, que se encontrava $\mathrm{em}$ profundo colapso material, num país de grandeza material. Por esta mesma razão, reclamamos o direito de proteger o nosso trabalho de modo a que não possa ser prejudicado por elementos criminosos e pelos lunáticos.
Quem prejudicar esta missão é inimigo do povo, quer o faça sua qualidade de democrata bolchevista, terrorista revolucionário ou sonhador reaccionário. Nestes tempos difíceis, aqueles que agem em nome de Deus nâo são aqueles que, citando a Bíblia, vagueiam ocionome de Deus a sadia sem fazer nada e a criticar o trabalho dos o forma mais nobre de dos outros: são aqueles cujas preces to
unir o homem a Deus, isto é, o trabalho.

Eu tinha o direito de me virar contra todos aqueles que, em vez de ajudarem, pensavam que a sua missão era criticarem a nossa obra. As naçб̄es estrangeiras não contribuíram com nada a não ser esse espírito, pois a sua rejeição tingiu-se de ódio ou de um sentimento de que sabem mais do que nós.

O ABC do nosso credo consistiu em encontrarmos apoio na nossa própria força. O nível de vida da nação é o resultado da sua produção total; por outras palavras, o valor de cada salário corresponde ao total; por outras palavras, o valor de cada salário corresponde ao
volume de bens produzidos como resultado do trabalho desempevolume de bens produzidos como resultado do trabalho desempe-
nhado. Esta doutrina não é nada popular numa altura em que se ouvem gritos de «melhores salários e menos trabalhow.

A seguir aos Estados Unidos, a Alemanha é hoje o maior produtor de aço do mundo. Poderia dar-vos muito mais exemplos. São provas decumentais de uma documences de us rulados do estes sucesos, jur cestâo constantemente em crise pensem que poden criticar-nos e dar-nos conselhos?

Proporcionámos à nação alemã essa arma de aço que constitui uma barreira nas nossas fronteiras contra as intençôes da malicios campanha da imprensa internacional.

No final da próxima década, o povo alemão recordará o êxito da sua eficiência e encher-se-á de um orgulho supremo. Um destes feito é a construção de uma liderança nacional tão afastada da democracia parlamentar como da ditadura militar.

Se a agitação ou a malícia internacionais tentarem quebrar a paz do Reich, $o$ aço $e$ o ferro protegerão o povo alemão e os seus lares. $O$ mundo verá então, com a rapidez de um relâmpago, até que ponto este Reich, povo, partido e forças armadas estão fanaticamente inspirados com um $s 6$ espírito, uma única vontade.
Se a Grã-Bretanha se desintegrasse subitamente e a Inglaterra ficasse apenas dependente do seu próprio território, talvez os Ingleses compreendessem melhor a seriedade das tarefas económicas com que nos confrontamos. Se uma nação que não possui reservas de ouro, divisas - não porque é governada pelo nacional-socialismo, mas porque um estado parlamentar e democrático foi explorado durante quinze anos por um mundo ávido de despojos - por outras palavras, se uma naçấo que tem que alimentar 140 pessoas por quilómetro quadrado e não possui colónias, se uma nação que carece de numerosas matérias-primas e não está disposta a viver uma vida ilusória a crédito, reduz o número de desempregados para zero em cinco anos e melhor o seu nivel de vida todos aqueles que. apesar de grandes valhora o seu nivel de vides todos aqueles que, apesar de grandes vantagens económicas, dificilmente conseguem resolver os seus problemas de

A reivindicação da posse das colónias alemãs será, portanto, ouvida todos os anos com um vigor crescente. Estas possessōes, que a Alemanha não roubou a outros países e que hoje não valem quase nada para essas potências, são indispensáveis para o nosso povo.

Gostaria de refutar aqui a esperança de que estas reivindicações podem ser evitadas através da concessão de créditos. Acima de tudo, não desejamos promessas ingénuas de que poderemos comprar o que necessitarmos. Rejeitamos este tipo de afirmaçס̃es de uma vez por todas.

Não estão com certeza à espera que eu discuta detalhadamente os diferentes planos internacionais que parecem despertar os diversos interesses dos vários governos. São demasiado incertos e falta-lhes a clareza necessária para que eu me possa pronunciar sobre essas questổes. Acima de tudo, no entanto, tomai nota da minha profunda desconfiança de todas as chamadas conferências que poderão proporcionar várias horas de conversa interessente a0s paric

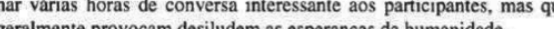

Não posso permitir que as nossas legítimas reivindicaçōes sejam ligadas a questōes políticas. Recentemente, têm surgido rumores de que a Alemanha estaria em vias de rever a sua opinião relativamente ao seu regresso à Liga das Naçōes. Gostaria, mais uma vez, de afirmar que o tratado de paz de 1919 foi imposto a alguns países. Este tratado provocou consequências a longo prazo nas vidas dos povos envolvidos. Esta violação dos destinos nacionais e económicos e da vida

comunitária das nações aconteceu debaixo de um véu de frases moralizadoras, talvez destinado a apaziguar a consciência pesada dos responsáveis.

Depois da revisão do mapa do mundo e das esferas territoriais raciais, revisão tão exaustiva como fundamental, ter sido levada cabo pela força, foi fundada uma Liga das Nações cuja missão consistia em cristalizar estes loucos e insensatos procedimentos e coordenar os seus resultados numa imutável e eterna base de vida.

Tenho notado que os políticos ingleses nos devolveriam de bom grado as nossas colónias se não os preocupasse tanto a ideia dos males e da violência que seriam infligidos aos nativos.

Nenhum desses impérios coloniais nasceu de um plebiscito. Hoje. são partes naturalmente integrais dos estados em questão e formam, como tal, parte da ordem mundial que sempre nos foi referida, em particular pelas políticas democráticas, como a «ordem mundial do direiton.

A Liga das Nações recebeu agora ordens para proteger esse direito. Não consigo compreender porque é que uma nação que foi
roubada pela força se deva juntar a tão ilustre companhia, e não posso roubada pela força se deva juntar a tão ilustre companhia, e não posso
permitir que se conclua que não estamos preparados para lutar pelos permitir que se conclua que não estamos preparados para lutar pelos
princípios da justiça só porque não estamos na Liga das Nações. Pelo princípios da justiça só porque não estamos na Liga das Nações. Pelo contrário, nós não pertencemos à Liga das Nações porque acreditamos que não é uma instituição de justiç

No entanto, devo acrescentar algumas consideraçōes relevantes.

Em primeiro lugar, saímos da Liga das Nações porque - leal às suas origens e obrigaçōes - nos negou o direito ao rearmamento e segurança.

Em segundo lugar, nunca regressaremos porque não pretendemos deixar que nos usem, através de uma votaçao por maioria, para defesa de injustiças em qualquer parte do mundo.

Em terceiro lugar, pensamos que agradaremos a todas as nações que, desafortunadamente, são levadas a confiar e a contar com a Lig das Naçōes como uma fonte de ajuda genuína. Pensamos que teria sido mais correcto, por exemplo, no caso da guerra da Etiópia, que Liga das Naçōes tivesse mostrado mais compreensão pelas necessidades vitais dos Italianos e menos inclinação para ajudar os Etíopes com 
promessas. Talvez isso tivesse permitido uma solução mais simples e razoável do problema.

Em quarto lugar, em caso algum permitiremos que a nação alemã se envolva em conflitos nos quais não está interessada. Nào estamos dispostos a lutar pelos interesses económicos ou territoriais de outros sem obter um mínimo de benefícios visiveis para os Alemães. Além do mais, não esperamos esse tipo de apoio de outros. A Alemanha está determinada a impor a si própria sensatez e moderação nos seus interesses e exigencias. Mas se os interesses da Alemanha estiveram seriamente ameaçados, não esperaremos receber o apoio da Liga das Nações e assumiremos, desde o início, o direito de arcar nós próprios com a tarefa.

Em quinto lugar, não pretendemos deixar que o nosso comportamento seja determinado, no futuro, por uma instituição internacional mento seja derer

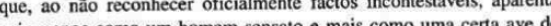
agir menos como um homen sento grande porte. Os interesses das naçoes, no que respecia à sua existência ou não existencia, sấ mas fortes do quve cences formalistas. Em 2038, é possível que tenham surgido novos estados e que outros tenham desaparecido sem que este novo estado de coisas tenha sido registado em Genebra.

A Alemanha não tomará parte em procedimentos tão insensatos como membro da Liga das Nações.

Apenas com um único país desdenhámos iniciar relaçōes. Esse stadó é a Rússia soviética. Mais do que nunca, vemos no bolchevismo a incarnação das forças destrutivas humanas. Não culpamos o povo russo por esta tervel ideologia de destriço. Sabemos que foi um pequeno grupo de judeus intelectuais que conduziu esta grande nação à sua situaçāo de loucura. Se esta doutrina se confinasse territorialmente à Russia, talvez rosse suporivel. Infelizmente, o bolchevismo internacional judeu tenta insinuar-se nas nações do mundo partir do seu centro soviético.

Como já afirmei mais do que uma vez, a Alemanha nâo tem mais exigências territoriais a fazer à França na Europa. Com a devolução do Sarre, estamos convictos de que o período de desavenças territoriais franco-alemãs está finalmente encerrado.

A Alemanha também nāo tem disputas com a Inglaterra, a não ser relativamente às suas reivindicaçōes coloniais. No entanto, não existe nenhuma causa concebível de conflito. A única coisa que tem envenenado e prejudicado a vida comum nestes dois países é a completamente insuportível campanha da imprensa que em ambos os países se mente insuportável campanha da imprensa que em ambos os paises

O governo britânico deseja a limitação dos armamentos ou a proibição dos bombardeamentos. Eu próprio propus a mesma coisa há algum tempo atrás. Contudo, também sugeri então que o mais importante era prevenir o envenenamento da opinião pública mundial através e a prigos infames $n$ imprensa. 0 que fortaleceu a nossa simpatia pela Itílin se is fosse possivel, é o facto de que nesse país a política pela Itália, se isto fosse possivel, candam de mãos dadas.

Existem mais de dez milhőes de alemães em estados adjacentes à Alemanha que antes de 1866 estavam ligados ao grosso da nação alemã por um elo nacional. Até 1918, combateram na Grande Guerra ombro a ombro com os soldados alemães do Reich. Contra a sua vontade foram impedidos, pelos tratados de paz, de se unirem ao Reich.

Isto foi extremamente penoso, mas não tenhamos dúvidas sobre uma coisa: a separação política do Reich nâo pode levar à privação de direitos, isto é, dos direitos gerais de autodeterminação racial que nos fireitos, isto é, dos diros condição para o armistício. Não o podemos ignorar só porque este é uma situação que envolve os Alemães.

Acaba por tornar-se insuportável para uma potência mundial, consciente de si própria, saber que existem cidadãos ao seu lado ao quais são constantemente infligidos os mais duros sofrimentos devido is suas simpatias ou comunhão com a nação como um todo, a sua fé e filosofia.

Sabemos que praticamente não existe uma linha de fronteira na Europa que satisfaça a todos. Deveria, por isso, ser ainda mais impor政 sofrimento da separação política o sofrimento da perseguição por pertencerem a um determinado povo.

Está provado que é possível encontrar caminhos para aliviar as Esta pres a tensōes. Mas aqueles que tentam eviar pela inevitavelmente um dia por criando 政

\section{Adory Hitler}

rar muitas dessas contínuas perseguiçōes do povo alemão nas suas fronteiras.

Mas tal como a Inglaterra defende os seus interesses em todo o lobo, a Alemanha de hoje saberá proteger os seus interesses mais globo, a Alemanha de hoje saberá proteger os seus interesesces também a proteç̧âo los povos germânicos ao longo das nossas fronteiras que não se encontram em posiçẫo de defender sozinhos a sua liberdade política e filosófica.

Posso dizer que desde que a Liga das Naçōes abandonou as suas contínuas tentativas para provocar agitaçăo em Danzig e desde a checo do novo comis rio, este local o mais perigoso para a paz gada do novo comissário, cste local

A Polónia respeita as condiçōes nacionais na cidade livre de Danig a Alemanha respeita os direitos polacos.

Falemos agora da Áustria. O que liga o Reich e a Áustria não é Falo apenas o mesmo pov

As dificuldades que surgiram na implementação do acordo de 11 Julho de 1936 tornaram essencial uma tentativa de eliminar os malentendidos e obstáculos à reconciliação final. É evidente que, quer quiséssemos ou não, poderia ter-se desenvolvido uma situação intolerável e potencialmente catastrófica. Não está nas mãos do homen parar o curso de um destino que, por negligência ou falta de senso, fo desencadeado.

Apraz-me dizer que estas ideias estão de acordo com o ponto de ista do chanceler austríaco, a quem convidei para uma visita. A vista do chanceler anstrinco, a quem colvide pas noses relactes intenção subjacente foi criar um desanuviamento das nossas relaçốcs que garantisse aos simpatizantes do nacional-socialismo

Ao mesmo tempo, haveria um acto de conciliação sob a forma de uma amnistia geral e de um melhor entendimento entre os dois estado através de relaçōes mais estreitas e amigáveis nas várias esferas da cooperacão cultural, política e económica. Tudo isto é um desenvolvimento no âmbito do tratado de 11 de Julho.

Desejo prestar um tributo ao chanceler austríaco pelos seus esforDesejo prestar um tributo ao chanceler auminho que é tanto do ços para encontrar, juntamente comigo, um caminho que é tanto do
interesse dos dois países como de todo o povo germânico, do qual todos somos filhos independentemente do nosso local de nascimento. Penso que desta forma demos o nosso contributo para a paz na Europa.

As relaçōes satisfatórias que mantemos com os outros países são do conhecimento geral. Acima de tudo, deve mencionar-se a nossa cooperação com as duas grandes potências que, como a Alemanha, identificaram o bolchevismo como um perigo mundial e estâo determinadas a resistir em conjunto ao Comintern. É meu sincero desejo ver esta cooperação com a Itália e o Japão cada vez mais alargada.

O povo alemão não é um povo bélico. É uma nação marcial, o que significa que não deseja a guerra mas não a teme. Ama a paz mas também ama a sua honra e a sua liberdade.

O novo Reich não pertencerá a nenhuma classe nem a nenhuma profissão, mas sim ao povo alemão. Ajudará o povo a encontrar um caminho mais fácil neste mundo. Ajudá-lo-á a tornar o seu destino mais feliz. O partido, o estado, as forças armadas e a economia săo instituições e funçס̃es que apenas podem ser vistas como um meio para atingir um fim. Serão julgadas pela história de acordo com os serviços que prestarem para atingir esse fim. Todavia, o seu objectivo é servirem o povo.

Peço agora a Deus que, nos anos que ấ vâem, abençoe o nosso trabalho, as nossas acçōes, a nossa previdência, a nossa determinação; que o Todo-poderoso nos proteja da arrogância e da subserviência que cobarde; que nos ajude a encontrar o caminho certo que traçou para o povo alemão e que nos dê sempre a coragem para fazer o que está correcto e não esmorecer ou fraquejar perante nenhum perigo ou poder.

Longa vida à Alemanha $\mathrm{e}$ ao povo alemão! 